\title{
Pelatihan Penerapan Model Pembelajaran Berbasis Konservasi (PBK) Pada Anak Usia Dini Di Lembaga Paud Al-Khair Udayana Mataram
}

\author{
Nurul Iman*, Khairul Huda \\ Universitas Pendidikan Mandalika, Jl. Pemuda No. 59A, Mataram, 83125 Indonesia \\ ${ }^{*}$ Corresponding author email: nuruiliman@ikipmataram.ac.id
}

\section{Diterima: Agustus 2019; Revisi: Oktober 2019; Diterbitkan: November 2019}

\begin{abstract}
Abstrak
Tujuan kegiatan pengabdian kepada masyarakat yang dilaksanakan dalam bentuk pelatihan penerapan model pembelajaran berbasis konservasi (PBK) di Lembaga PAUD Al- Khair Udayana Mataram ini adalah: 1) Untuk mendeskripsikan rancangan model PBK pada anak usia dini; 2) Untuk memberikan pengetahuan dan pengalaman kepada para pendidik tentang pentingnya menerapkan model PBK pada anak usia dini. Hal ini didasarkan atas masih kurangnya efektifitas dan kebermaknaan dalam mengembangkan karakter peduli lingkungan bagi anak. Hal ini dibuktikan dengan rendahnya rasa cinta dan peduli lingkungan pada diri anak misalnya membuang sampah di sembarang tempat. Metode yang digunakan dalam kegiatan pengabdian kepada masyarakat ini adalah pelatihan dan pendampingan yang bersifat partisipatif. Hasil pelatihan ini adalah peserta pelatihan memahami dan menguasai rancangan model PBK. Adapun dampak dari kegiatan pengabdian ini adalah memberikan manfaat bagi para pendidik dalam hal ini adalah guru PAUD supaya bisa memilih model PBK sebagai alternatif dalam proses pembelajaran pada anak usia dini sebagai usaha menanamkan karakter peduli lingkungan pada anak sehingga terlahir anak-anak yang mau menjaga kelestarian lingkungan sekitar serta sehat jasmani maupun rohani.
\end{abstract}

Kata Kunci: Penerapan Model PBK; Anak Usia Dini

\section{Training on the Application of Conservation-Based Learning (PBK) Models in Early Childhood at the Udayana Mataram Institute for Early Childhood Education}

\begin{abstract}
The objectives of community service activities carried out in the form of training on the application of a conservation-based learning model (PBK) at the Al-Khair Udayana Mataram PAUD are: 1) To describe the design of the PBK model in early childhood; 2) To provide knowledge and experience to educators about the importance of applying the PBK model in early childhood. This is based on the lack of effectiveness and meaning in developing the character of caring for the environment for children. This is evidenced by the low feeling of love and care for the environment in children, for example throwing trash in any place. The method used in this community service activity is participatory training and mentoring. The result of this training is that the training participants understand and master the design of the PBK model. The impact of this service activity is to provide benefits for educators, in this case, early childhood teachers so that they can choose the PBK model as an alternative in the learning process in early childhood as an effort to instill a caring character for the environment in children so that children who want to protect the environment are born around as well as physically and mentally healthy.
\end{abstract}

Keywords: Application of the PBK Model; Early Childhood

How to Cite: Iman, N., \& Huda, K. (2019). Pelatihan Penerapan Model Pembelajaran Berbasis Konservasi (Pbk) Pada Anak Usia Dini Di Lembaga Paud Al-Khair Udayana Mataram. Lumbung Inovasi: Jurnal Pengabdian kepada Masyarakat, 4(2), 43-49. doi:https://doi.org/10.36312/linov.v4i2.453 


\section{PENDAHULUAN}

Anak adalah amanah dari Allah SWT, anugerah terindah dan harta yang tidak ternilai harganya yang harus dididik dengan sebaik-baiknya. Dalam memberikan pendidikan pada anak sejak usia dini, saat ini telah banyak lembaga pendidikan baik formal, informal, maupun nonformal yang telah diberikan kepercayaan untuk memberikan pendidikan dan mengembangkan potensi anak, salah satunya adalah lemabaga pendidikan anak usia dini (PAUD).

Masa depan anak sangat ditentukan dari pendidikan yang didapatkannya sejak usia dini. Pendidikan anak usia dini merupakan pilar utama yang menentukan baik buruknya perkembangan dan masa depan anak, baik itu berkaitan dengan perkembangan moral, agama, kognitif, fsikomotorik, sosial-emosionsl, bahasa, dan afektif (kepribadian) anak itu sendiri. Pembinaan dan pengembangan potensi anak dapat diupayakan melalui pendidikan seperti lembaga pendidikan anak usia dini (PAUD) sebagai suatu wadah untuk membina karakter serta menggali potensi anak sejak dini yang didukung oleh masyarakat khususnya keluarga terdekat dengan anak.

Pada zaman era globalisasi ini, salah satu karakter yang terabaikan penanamannya oleh para pendidik di sekolah adalah karakter peduli lingkungan. Era globalisasi membuat manusia seakan-akan lupa akan pentingnya lingkungan dalam kehidupannya karena mereka kurang puas terhadap sesuatu yang dimilikinya. Mereka mengeksploitasi alam secara besarbesaran hanya untuk memperkaya diri sehingga mereka lupa untuk menjaga keseimbangan alam yang ada, sehingga kerusakan lingkungan terjadi hampir di seluruh belahan bumi (Suwito, 2011). Karakter peduli lingkungan oleh banyak kalangan telah memudar dan tidak memeperhatikan lagi apa dampak perbuatan mereka terhadap lingkungan hidup (Markowitz, 2013). Kerusakan lingkungan juga telah terjadi di sekolah dan lingkungan sekitar.

Adapunfakta-fakta yangditemukan saat ini yaitu:masihadaanak bahkan orang yang sudah dewasa membuang sampah (tisu,bungkusmakanan, plastik bungkus spidol, dan lain sebagainya) tidak pada tempatnya dan perilaku tersebut diabaikan oleh guru ataupun orang tua. Hal ini terjadi karena kurangnya kesadaran siswa, pendidik dan orang tua dalam menjaga dan melestarikan lingkungannya. Karakter peduli lingkungan pada anak sejatinya mendapatkan perhatian lebih dan ditanamkan melalui pembiasaan khususnya di sekolah. (Prayitno \& Dahoelat. 2019) Salah satu langkah yang dilakukan adalah mengubah perilaku seseorang dengan menanamkan sikap cinta lingkungan bagi anak didik sedini mungkin melalui lembaga pendidikan di lingkungan sekolah

Karakter peduli pada lingkungan untuk anak usia dini dapat dikembangkan dengan menanamkan nilai-nilai konservasi sebagai upaya mengatasi masalah kerusakan lingkungan. Konservasi adalah pelestarian atau perlindungan. Secara harfiah, konservasi berasal dari bahasa inggris conservation yang artinya pelestarian atau perlindungan (Daryanto, 2013: 91). Pendapat lain menyatakan konservasi adalah upaya pemeliharaan dan perlindungan sesuatu secara teratur untuk mencegah kerusakan dengan cara memperbaiki, mengawetkan, dan melestarikan nya (Depdiknas, 2012). Oleh karena itu konservasi juga merupakan upaya yang dilakkukan manusia untuk melestarikan atau melindungi alam agar tetap terjaga kelestariannya. Penanaman pendidikan karakter di sekolah khususnya pada lembaga pendidikan anak usia dini diperlukan upaya yang maksimal, maka salah satu upaya yang dapat dilakukan adalah dengan menerapkan pembelajaran berbasis konservasi. Pembelajaran ini merupakan suatu pembelajaran yang peneliti desain sebagai usaha untuk mengatasi masalah kerusakan lingkungan dan antisipasi kaitannya dengan perkembangan karakter peduli lingkungan pada anak usia dini.

Pembelajaran berbasis konservasi adalah suatu rencana atau pola pembelajaran yang menitik beratkan pada penanaman nilai-nilai konservasi dan peningkatan karakter peduli lingkungan untuk anak. Makna konservasi dapat meliputi seluruh kegiatan pemeliharaan sesuai dengan situasi dan kondisi setempat. Nilai-nilai koservasi yang perlu ditumbuhkembangkan dan dipelihara yaitu nilai menanam, memanfaatkan, melestarikan, dan mempelajari dalam arti fisik dan non-fisik (Rachman, 2012).Pengenalan nilai-nilai konservasi pada anak sejak usia dini sangat penting untuk ditanamkan di sekolah, namun fakta yang terjadi dilapangan hanya sebagian kecil dari sekolah yang melakukannya, hal ini disebabkan oleh kurangnya kesadaran pendidik. Adapun nilai-nilai konservasi yang perlu ditanamkan 
pada anak usia dini adalah bagaimana menghemat (reduce), menggunakan kembali (reuse) dan mendaur ulang (recycle) diterapkan dalam proses pembelajaran baik dalam maupun luar kelas.

Berdasarkan pada uraian di atas, kegiatan pengabdian pada masyarakat perlu untuk dilaksanakan melalui penyelenggaraan pelatihan sebagai upaya penjaminan mutu pendidikan anak usia dini khususnya dalam penerapan model pembelajaran berbasis konservasi (PBK). Sehubungan dengan permasalahan yang dihadapi oleh Guru di Lembaga PAUD AI- Khair Udayana Mataram, terkait permasalahnya adalah,masih ada anak-anak bahkan orang yang sudah dewasa membuang sampah (tisu, bungkus makanan, plastik bungkus spidol, dan lain sebagainya) tidak pada tempatnya dan perilaku tersebut diabaikan oleh guru ataupun orang tua. Hal ini terjadi karena kurangnya kesadaran siswa, pendidik dan orang tua dalam menjaga dan melestarikan lingkungannya di sekolah sekaligus sebagai mitra kegiatan.

Pelatihan dilakukan denganpendampingan dalam penerapan model pembelajaran berbasis konservasi (PBK) dengan harapan; (a) Diharapkan peserta memahami cara dalam melestarikan lingkungan, (b) Menjaga kebersihan dengan membuang sampah pada tempatnya, (c) Pelatihan memberikan pengalaman bermakna kepada siswa, (d) Kegiatan pelatihan PBK dilaksanakan melalui kerja kelompok , berdiskusi, dan saling mengoreksi, (e) Kebersamaan, kerjasama, dan saling memahami satu dengan yang lain secara mendalam merupakan aspek pembelajaran yang menyenangkan, (f) Pembelajaran dilaksanakan secara aktif, kreatif, produktif dan mementingkan kerjasama dan pembelajaran dilaksanakan dengan cara menyenangkan. Pendampingan dilakukan melalui kegiatan pendampingan informal yang berkesinambungan untuk terus melaksanakan penerapan model pembelajaran berbasis konservasi (PBK) pada guru dan anak didik.

\section{METODE PELAKSANAAN}

Adapun Program Pengabdian pada Masyarakat (PKM) dilaksanakan sesuai dengan jadwal yang telah ditentukan. Pelaksanaan kegiatan dilakukan dengan beberapa langkah antara lain.

1. Perencanaan meliputi (a) Survei dan analisis lokasi kegiatan; kegiatan ini diperlukan untuk mendapatkan informasi kondisi sosial budaya lembaga, karakteristik anak, kondisi lingkungan masyarakat. Informasi ini sangat diperlukan untuk merancang pelaksanaan program PKM yang efisien dan efektif; (b) Melaksanakan sosialisasi melalui FGD (Fokus Grup Diskusi); (c) Tim PKM dan anggota mitra secara bersama-sama mempersiapkan semua bahan dan peralatan yang diperlukan selama pelaksanaan program PKM; dan (d) Pengadaan media belajar; untuk memudahkan proses pelatihan maka peserta diberikan materi pelatihan.

2. Tindakan meliputi (a) Peningkatan pengetahuan model pembelajaran berbasis konservasi kepada kelompok mitra melalui kegiatan pelatihan, metode yang digunakan adalah ceramah, Tanya jawab, dan diskusi. Materi yang disampaikan antara lain: Hakikat Model PBK, Urgensi penerapan Model PBK, dan Teknik atau Langkah-langkah Penerapan Model PBK. Untuk mengetahui adanya peningkatan pengetahuan atas materi yang disampaikan, mitra diberikan pretes dan posttest; (b) Pelatihan, kegiatan ini bertujuan untuk meningkatkan keterampilan mitra dalam hal ini, guru dan pengasuh dalam menjalankan proses pembelajaran; (c) Pendampingan; kegiatan ini dilakukan untuk meningkatkan pemahaman guru dalam menerpakan model PBK. Pendampingan dilakukan secara berkelanjutan sampai mitra benar-benar sudah menguasai teknik penerapan model PBK.

\section{HASIL DAN PEMBAHASAN \\ Deskripsi Pelaksanaan Pelatihan}

Pelaksanaan kegiatan pelatihan penerapan model pembelajaran berbasis konservasi (PBK) ini telah dilaksanakan bertempat di di Lembaga PAUD Al- Khair Udayana Mataram, Kota Mataram. Adapun peserta yang mengikuti proses pelatihan adalah guru dan murid-murid yang ada di Lembaga PAUD Al- Khair Udayana Mataram, Kota Mataram.

Respon dari peserta terkait dengan kegiatan pelatihan ini sangat positif dan mendukung dengan baik, hal ini terindikasi dari peserta pelatihan yang aktif (partisipatif) dalam mengikuti 
proses kegiatan dan peserta mampu bekerjasama untuk memecahkan permasalahan yang relevan dengan materi pelatihan yang disampaikan. Selain itu, peserta pelatihan yang merupakan guru Lembaga PAUD Al- Khair Udayana itu sendiri antusias selama proses penyampaian materi pelatihan. Selama proses pelatihan, banyak topik-topik (bahan) materi yang didiskusikan antara peserta dengan Tim pengabdian secara dialogis dengan mengedepankan pada pendekatan problem based learning. Materi-materi yang disampaiakan oleh Tim pengabdian merupakan kompilasi materi yang telah disusun berdasarkan pada aspek relevansi (kesesuaian)dan urgensi penguatan serta penguasaan materi. Secara spesifik, materi Karakter peduli pada lingkungan untuk anak usia dini dapat dikembangkan dengan menanamkan nilai-nilai konservasi sebagai upaya mengatasi masalah kerusakan lingkungan. Konservasi adalah pelestarian atau perlindungan. Secara harfiah, konservasi berasal dari bahasa inggris conservation yang artinya pelestarian atau perlindungan (Daryanto, 2013: 91).Oleh karena itu konservasi juga merupakan upaya yang dilakkukan manusia untuk melestarikan atau melindungi alam agar tetap terjaga kelestariannya dan bertujuan: 1) Untuk mendeskripsikan rancangan model pembelajaran berbasis konservasi (PBK) pada anak usia dini; 2) Untuk memberikan pengetahuan dan pengalaman kepada para pendidik tentang pentingnya menerapkan model pembelajaran berbasis konservasi (PBK) pada anak usia dini.

Selama kegiatan pelatihan berlangsung, Tim pengabdian juga berupaya untuk melakukan monitoring terkait dengan proses pelatihan untuk mengetahui secara jelas kelemahan atau kekurangan yang ada. Monitoring ini juga merupakan salah satu bentuk dari penjaminan mutu kegiatan pelatihan dan sebagai upaya memberikan garansi bagi peserta pelatihan terhadap fungsionalitas (kebermanfaatan) dari hasil pelatihan bagi penguatan kompetensi dalam melakukan evaluasi program khususnya dalam meningkatkan pemahaman guru dalam menerpakan model Pembelajran Berbasis Konservasi (PBK).Khusus untuk sesi Diskusi (Tanya Jawab), banyak peserta pelatihan yang mengajukan pertanyaan terkait dengan materi. Peserta pelatihan terlihat antusias untuk dapat menguasai secara komprehensif. Terkait dengan cara pengembangan instrument disesuaikan dengan panduan dan prosedur yang tepat yang sudah dirancang sebelumnya.

\section{Evaluasi Kegiatan}

Setelah penyampaian materi dan pelaksanaan praktek kemampuan menerpakan model Pembelajran Berbasis Konservasi (PBK). dilakukan, Tim pengabdianberupaya untuk melakukan evaluasi terhadapimplementasi dari pelatihan yang diselenggarakan. Evaluasi ini bertujuan untuk mengetahui tingkat keberhasilan dari pelaksanaan kegiatan pelatihan yang dilakukan.

\section{Evaluasi Proses}

Evaluasi proses ini berupaya untuk mengetahui tingkat partisipasi, respon, dan pemahaman terhadap materi pelatihan yang disampaikan kepada peserta. Dari sisi partisipasi, yang ditargetkan mengikuti pelatihan ini adalah guru di LembagaPAUD AL- Khair Udayana Mataram. Dalam kenyataannya, hampir semua peserta hadir dan ikut berpartisipasi aktif selama kegiatan pelatihan berlangsung. Kemudian, respon peserta terhadap kegiatan pelatihan ini menunjukkan dukungan yang positif dan memandang perlu untuk mengembangkan kegiatan sejenis yang dapat berkesinambungan. Terkait dengan respon peserta terhadap pelaksanaan kegiatan pelatihan ini, berikut ini adalah data grafik mengenai respon peserta terhadap pelatihan peningkatan kemampuan kognitif anak melalui pendekatan contextual teaching and learning. 


\section{Respon Peserta terhadap Pelaksanaan Pelatihan}

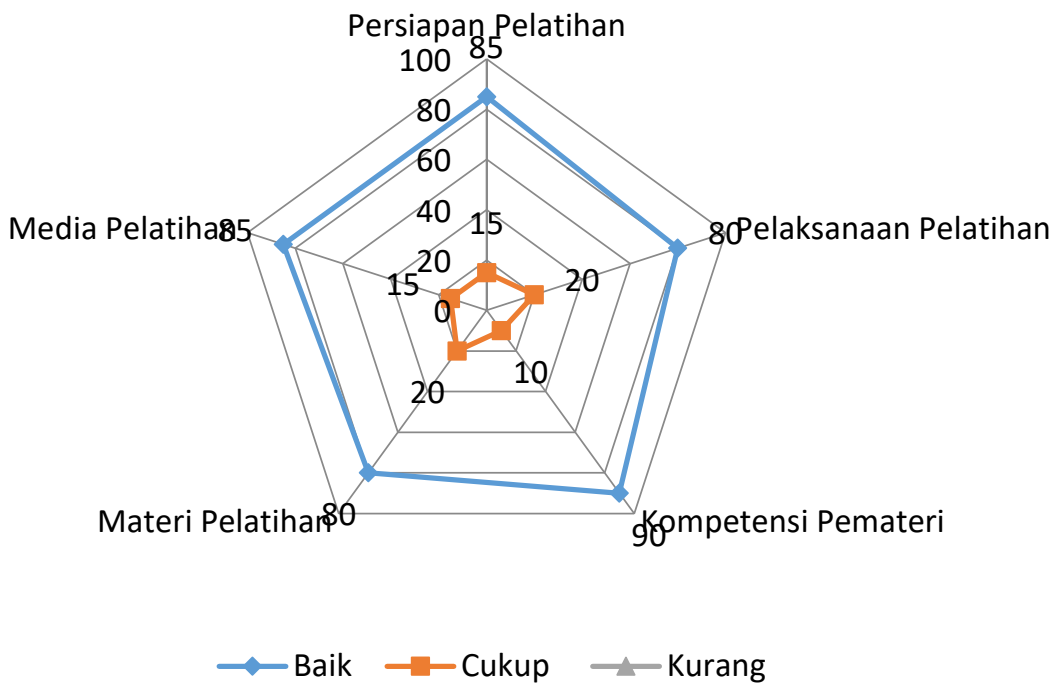

Gambar 1. Respon Peserta Terhadap Pelaksanaan Pelatihan

Berdasarkan data pada gambar grafik di atas, dapat dijelaskan bahwa pada: (1) Aspek Persiapan Pelatihan, peserta menjawab $85 \%$ baik dan $15 \%$ cukup; (2) aspek Pelaksanaan Pelatihan, peserta menjawab $80 \%$ Baik dan $20 \%$ cukup; (3) aspek Kompetensi Pemateri, peserta pelatihan menjawab 90\% baik dan hanya 10\% cukup;(4) Aspek Materi Pelatihan, peserta menjawab $80 \%$ baik dan 20\% cukup; dan (5) aspek Media Pelatihan, peserta menjawab $85 \%$ baik dan $15 \%$ cukup.

\section{Evaluasi Hasil}

Pada aspek evaluasi hasil pelatihan ini, Tim Pengabdian berupaya untuk melakukan evaluasi terkait dengan penggunaan pendekatan contextual teaching and learning dalam meningkatkan kemampuan kognitif anak. Khusus pada aspek praktik dengan penggunaan jenis media yang berbasis kontextual, peserta melakukan praktik evaluasi dalam pendekatan kontextual teaching and learning, pada aspek; (1) penentuan jenis media yang digunakan; (2) formulasi tujuan; (3) pengembangan instrument kemampuan menerpakan model Pembelajran Berbasis Konservasi (PBK).; (4) penentuan model-metode yang digunakan dalam penerapan menerpakan model Pembelajran Berbasis Konservasi (PBK). (5) pengumpulan dan pengolahan data terkait dengan kemampaun menerpakan model Pembelajran Berbasis Konservasi (PBK).; (6) serta pengambilan kesimpulan dan pengambilan keputusan terhadap aspek kemapuan menerpakan model Pembelajran Berbasis Konservasi (PBK). Terkait dengan evaluasi hasil kegiatan pelatihan ini, Tim Pengabdian berupaya melakukan observasi (pengamatan) secara cermat dan memberikan penugasan praktik kerja (mandiri) secara langsung kepada peserta pelatihan untuk mengetahui penguasaan pemahaman materi.

Mengacu pada indikator keberhasilan kegiatan pelatihan ini, secara umum pelaksanaan kegiatan pelatihan pendekatan kontextual teaching and learning ini telah mencapai indikator keberhasilan yang telah ditentukan. Indikator keberhasilan dari pelaksanaan kegiatan pelatihan ini antara lain:

1. Peserta pelatihan aktif (partisipatif) dan bekerjasama dengan baik selama mengikuti kegiatan, hal ini dapat terlihat dari tingkat kehadiran peserta, aktivitas diskusi dan tanya jawab antara peserta dan pemateri yang dialogis. Selain itu, peserta pelatihan kooperatif untuk dapat mendukung keterlaksanaan kegiatan pelatihan ini.

2. Peserta pelatihan memahami materi-materi pelatihan, hal ini dapat diukur dari pencapaian kemampuan memahami materi-materi pelatihan oleh peserta yang berada dalam kategori cukup menguasai. 
3. Peserta pelatihan mampu untuk melakukan praktek penggunaan model Pembelajaran Berbasis Konservasi (PBK).yang diselenggarakan, melalui penugasan mandiri peserta dapat melakukan evaluasi kegiatan praktik.

\section{Rencana Tindak Lanjut}

Kegiatan pengabdian kepada masyarakat melalui pelatihan penggunaan model Pembelajaran Berbasis Konservasi (PBK) di LembagaPAUD AL- Khair Udayana Mataramini tidak dilakukan secara parsial, artinya setelah selesai kegiatan, selesai pula seluruh aktivitasnya. Akan tetapi, pasca kegiatan pelatihan ini, Tim pengabdian akan terus berupaya untuk menindaklanjuti kegiatan yang telah dilaksanakan dengan mengidentifikasi kekurangan atau kelemahan khususnya dari aspek penguasaan materi pelatihan yang kurang dikuasasi dari peserta pelatihan khususnya dengan pendekatan contextual teaching and learning. Oleh karena itu, bentuk tindak lanjut yang akan dilakukan berupa kegiatan pendampingan informal yang berkesinambungan untuk terus meningkatkan pemahaman dan penguasaan kemampuan penggunaan model Pembelajaran Berbasis Konservasi (PBK) di LembagaPAUD AL- Khair Udayana Mataram.

\section{KESIMPULAN}

Pelaksanaan kegiatan pengabdian kepada masyarakat melalui pelatihan penggunaan model Pembelajaran Berbasis Konservasi (PBK) di Lembaga PAUD AL- Khair Udayana Mataram telah dapat terlaksana dengan baik dari sisi pengelolaan kegiatan, mulai dari persiapan, proses, dan hasil telah sesuai dengan tujuan dan indikator keberhasilan yang telah dirancang. Selain itu, pemahaman dan penguasaan peserta terhadap materimateri pelatihan yang disampaikan dapat diaplikasikan langsung dengan praktik penerapan penggunaan model Pembelajaran Berbasis Konservasi (PBK) sehingga pengetahuan dan pemahaman guru PAUD Al-Khair tentang hakikat model pembelajaran menjadi meningkatdan guru-guru PAUD Al-Khair dalam mengaplikasikan model pembelajaran beerbas isi konservasi meningkat. Meskipun dari beberapa sisi masih ada kekurangan, akan tetapi kegiatan ini akan terus ditindaklanjuti secara berkesinambungan untuk mendapatkan hasil kegiatan yang optimal.

\section{REKOMENDASI}

Kegiatan ini akan terus ditindaklanjuti secara berkesinambungan untuk mendapatkan hasil kegiatan yang optimal.

\section{UCAPAN TERIMAKASIH}

Terimakasih penulis ucapkan kepada seluruh pihak yang telah membantu pelaksanaan kegiatan pengabdian kepada masyarakat ini, diantaranya (1) LPPM IKIP Mataram yang telah mendukung pendanaan kegiatan ini, (2) rekan dosen dan serta mahasiswa Jurusan Pendidikan Luar Sekolah, Bimbingan Konseling, dan Pendidikan Matematika yang telah berpartisipasi aktif dan membantu terlaksananya kegiatan pengabdian ini, dan (3) pengelola dan Guru PAUD Al- Khair atas kerjasama dan partisipasinya.

\section{DAFTAR PUSTAKA}

Beaty, J. J. 2014. Observasi Perkembangan Anak Usia Dini. Jakarta: Kencana.

Daryanto \& Suprihatin, A. 2013. Pengantar Pendidikan Lingkungan Hidup. Yogyakarta: Gava Media.

Dirjen PAUDNI. 2012. Pedoman Pendidikan Karakter Pada Anak Usia Dini. Jakarta.

Djamarah, S. B. 2008. Psikologi Belajar. Jakarta: PT Rineka Cipta.

Fadlillah, M. 2014. Desain Pembelajaran PAUD Cet. Ke2. Yogyakarta: AR-Ruz Media.

Fathurrohman, P. \& Sutikno, M.S. 2011. Strategi Belajar Mengajar Melalui Penanaman Konsep Umum dan Konsep Islami Cet. Ke5. Bandung: PT Rifeka Aditama. 
Hamdani. 2011. Strategi Belajar Mengajar. Bandung: Pustaka Setia.

Hasbullah. 2008. Dasar-Dasar IImu Pendidikan. Jakarta: PT. Raja Grafindo Persada.

Handoyo,E \& Tijan. 2010. Model Pendidikan Karakter Berbasis Konservasi: Pengalaman Universitas Negeri Semarang. Semarang: Widiya Karya Press.

Iskandar. 2009. Psikologi Pendidikan Sebuah Orientasi Baru. Jakarta: Gaung Persada (GP) Press.

Itadz, M. 2008. Memilih, Menyusun, Dan Menyajikan Cerita Untuk Anak Usia Dini. Yogyakarta: Tiara Wacana.

Majid, A. 2014. Pembelajaran Tematik Terpadu. Bandung: PT Reamaja Rosdakarya.

Pendaki error. 2013. "Konservasi", http://www.pendakierror.com/Konservasi.html (online) diakses pada tanggal 24 September 2014.

Prayitno, A., \& Dahoelat, D., N., R. (2019) Penguatan Pendidikan Lingkungan Hidup dan Budaya Hijau Di SDN Kemiri 3 Menuju Green School. Sasambo: Jurnal Abdimas (Journal of Community Service), 18.doi:https://doi.org/10.36312/sasambo.v1i1.132

Rusman. 2014. Model-model Pembelajaran Mengembangkan Profesionalisme Guru Eddisi ke-2. Jakarta: Rajawali Pers.

Sugiyo. 2012. "Pengembangan Karakter Anak Melalui Konsenasi Moral Sejak Dini". Indonesian Journal of Conservation.Vol.1 No.1. Hal 40-41.

Suyanta, S. 2005.Pembelajaranuntuk Anak TK. Jakarta: Direktorat Jenderal Pendidikan Tinggi.

Suyadi. 2011. Manajemen PAUD TPA, KB, TK/ RA.: Yogyakarta: Pustaka Pelajar.

Suprijono, A. 2011. Cooverative Learning Teori dan Aplikasi PAIKEM. Pustaka Pelajar: Jakarta.

Suyanta, S. 2005.Pembelajaranuntuk Anak TK. Jakarta: Direktorat Jenderal Pendidikan Tinggi.

Sagala, S. 2010. Konsep dan Makna Pembelajaran. Bandung: Alfabeta. 